\title{
Environmental DNA (eDNA) reveals potential for interoceanic fish invasions across the Panama Canal
}

\author{
Lennart Schreiber ${ }^{1}$, Gustavo Castellanos-Galindo ${ }^{1}$, Mark Torchin ${ }^{1}$, Karina Chavarria ${ }^{1}$, \\ Silke Laakmann ${ }^{2}$, and Kristin Saltonstall ${ }^{1}$ \\ ${ }^{1}$ Smithsonian Tropical Research Institute \\ ${ }^{2}$ Helmholtz Institute for Functional Marine Biodiversity at the University of Oldenburg \\ (HIFMB)
}

August 30, 2021

\begin{abstract}
Interoceanic canals can facilitate biological invasions as they connect the world's oceans and dissolve dispersal barriers between bioregions. As a consequence, multiple opportunities for biotic exchange arise and the resulting establishment of migrant species often causes adverse ecological and economic impacts. The Panama Canal is a key region for biotic exchange as it connects the Pacific and Atlantic Oceans in Central America. In this study, we used two complementary methods (environmental DNA (eDNA) and gillnetting) to survey fish communities in this unique waterway. Using COI (cytochrome oxidase subunit I) metabarcoding, we detected a total of 142 taxa, including evidence for the presence of sixteen Atlantic and eight Pacific marine fish inside different sections of the Canal. Of these, ten are potentially new records of marine taxa detected in the freshwater segment of the Canal. Molecular data did not capture all species caught with gillnets, but generally provided a more complete image of the fish fauna. Diversity indices based on eDNA surveys revealed significant differences across different sections of the Canal reflecting in part the prevailing environmental conditions. The observed increase in the presence of marine fish species in the Canal indicates a growing potential for interoceanic exchange of fishes across the Isthmus. Monitoring using eDNA is a rapid and efficient way to assess potential changes in the fishes of this important waterway.
\end{abstract}

\section{Hosted file}

manuscript_eDNA_Canal_01jun21.docx available at https://authorea.com/users/431787/articles/ 535267-environmental-dna-edna-reveals-potential-for-interoceanic-fish-invasions-acrossthe-panama-canal

\section{Hosted file}

tables_figures_eDNA_Canal_01jun21.docx available at https://authorea.com/users/431787/ articles/535267-environmental-dna-edna-reveals-potential-for-interoceanic-fishinvasions-across-the-panama-canal 